\title{
Fluorescent treponemal antibody tests on cerebrospinal fluid
}

\author{
A. E. WILKINSON \\ Venereal Diseases Reference Laboratory, Public Health Laboratory Service, The London Hospital
}

There have been many evaluations of the absorbed fluorescent treponemal antibody (FTA-ABS) test on serum. Its reactivity on cerebrospinal fluid (CSF) is less well documented, although studies have recently been reported by Escobar, Dalton, and Allison (1970), Garner and Backhouse (1971), and Duncan, Jenkins, and Parham (1972). The last workers recommend the testing of undiluted and unabsorbed CSF, as described by Harris, Bossak, Deacon, and Bunch (1960), but they think that the specificity of this method needs further evaluation before it can be adopted as a routine test. In the FTA-ABS test anti-human immunoglobulin conjugates are used which react mainly with IgG antibody. O'Neill and Nicol (1972) have suggested that the presence of IgM anti-treponemal antibody in serum may reflect an untreated or recently treated infection and that this antibody is the first to disappear after treatment.

The present investigation had the following aims: (1) To determine the reactivity of the FTA-ABS test on CSF from patients with well documented evidence of syphilis representing all stages of the disease.

(2) To compare the reactivity of the unabsorbed FTA and FTA-ABS tests on CSF from patients thought not to have syphilis and from patients with neurosyphilis.

(3) To test normal CSF and CSF from patients with neurosyphilis for the presence of IgM anti-treponemal antibody.

\section{Material and methods}

CEREBROSPINAL FLUID This came from:

(a) 289 patients with definite evidence of syphilis at various stages who were attending the Whitechapel Clinic, the London Hospital (215), or Moorfields Eye Hospital (74). FTA-ABS, Reiter protein complementfixation (RPCF), and VDRL slide tests, and a cardiolipin Wassermann reaction were carried out as well as a cell count and protein estimation.

(b) 79 hospital patients with a variety of conditions; from the information on the request forms, syphilis was

Received for publication November 17, 1972

Some of the data were presented at a meeting of the M.S.S.V.D. on November 24, 1972 not suspected. RPCF and VDRL tests were performed and were negative on all 79 specimens. Unabsorbed FTA and FTA-ABS tests were also carried out.

(c) 79 specimens sent to the Reference Laboratory for checking, either because they had been found abnormal elsewhere, or because FTA-ABS or TPI tests were requested. The same serological tests were used as in Group $a$, together with an unabsorbed FTA test.

SEROLOGICAL TESTS TPI, FTA-ABS, RPCF, WR, and VDRL slide tests were carried out by the methods described in the P.H.L.S. Monograph No. 1 (1972). The unabsorbed FTA test followed the FTA-ABS procedure except that the CSF was tested unabsorbed and undiluted; if reactive, serial dilutions in buffered saline were tested and the end-point was taken as the highest dilution giving a definite $(1+)$ reading. In testing for IgM antibody, the CSF was tested undiluted, and diluted 1 in 5 in buffered saline and 1 in 5 in an ultrasonicate of Reiter treponemes; a conjugate specific for human IgM was used (Wellcome Reagents).

\section{Results and discussion}

Reactivity of FTA-ABS test on CSF from patients with syphilis

The clinical categories of these patients are shown in Table I. 240 were not thought to have neurosyphilis. Among these FTA-ABS tests were found reactive

TABLE I Clinical categories of patients in Group a

\begin{tabular}{|c|c|c|c|}
\hline \multirow[b]{2}{*}{ Stage of disease } & \multirow[b]{2}{*}{$\begin{array}{l}\text { No. of } \\
\text { patients }\end{array}$} & \multicolumn{2}{|l|}{ Treatment } \\
\hline & & Adequate & $\begin{array}{l}\text { None } \\
\text { or ina dequate }\end{array}$ \\
\hline $\begin{array}{c}\text { Primary Seronegative } \\
\text { Seropositive }\end{array}$ & $\begin{array}{r}7 \\
23\end{array}$ & $\begin{array}{r}7 \\
23\end{array}$ & - \\
\hline Secondary & 8 & 8 & - \\
\hline Latent First year & 7 & 4 & 3 \\
\hline Late & 46 & 11 & 35 \\
\hline ? Syphilis ? Yaws & 80 & 17 & 63 \\
\hline Cardiovascular & 3 & 3 & - \\
\hline ? Congenital ? Acquired & 11 & 1 & 10 \\
\hline Congenital & 55 & 17 & 38 \\
\hline Neurosyphilis & 49 & 26 & 23 \\
\hline Total & 289 & 117 & 172 \\
\hline
\end{tabular}


(that is, positive or doubtful) in nine; three had latent syphilis, one congenital syphilis, two either congenital or acquired syphilis, and three either latent syphilis or old yaws. In all nine the other serological tests on the CSF were negative; the cell count and protein level were within normal limits in seven, one had a cell count of 6 per cu. mm., and one a protein content of $50 \mathrm{mg} . / 100 \mathrm{ml}$. The significance of a reactive FTA-ABS test on CSF which is otherwise normal in the absence of clinical evidence of neurosyphilis is not known; it is possible that these nine patients had previously had asymptomatic neurosyphilis and that their spinal fluids were reverting to normal as a result of treatment, although this was thought to be inadequate in amount in three of these nine patients.

49 patients had neurosyphilis; the results of serological tests on their CSF are shown in Table II.

TABLE II Reactivity of serological tests on cerebrospinal fluid from 49 patients with neurosyphilis

\begin{tabular}{|c|c|c|c|}
\hline \multirow[b]{2}{*}{ Test } & \multicolumn{2}{|c|}{ Reactive } & \multirow[t]{2}{*}{ Negative } \\
\hline & No. & Per cent. & \\
\hline FTA-ABS test & 33 & 67 & 16 \\
\hline RPCF test & 20 & 41 & 29 \\
\hline VDRL slide test & 23 & 47 & 26 \\
\hline Cardiolipin Wassermann reaction & 24 & 49 & 25 \\
\hline
\end{tabular}

Clinical category:

$\left.\begin{array}{lr}\text { Tabes or tabo-paresis } & 19 \\ \text { Asymptomatic neurosyphilis } & 11 \\ \text { Pupillary changes } & 10 \\ \text { General paresis } & 4 \\ \text { Hearing Loss } & 3 \\ \text { Other } & 2\end{array}\right\} 49$

The FTA-ABS test was found to be the most sensitive, being positive in 33 cases, and in no case was it found to be negative when any of the others were reactive. It was the only test found positive on the CSF of one untreated and five adequately treated patients. Its correlation with the cell count and protein level is shown in Table III. If a white cell count above 5 per cu. mm. or a protein content above $40 \mathrm{mg}$. per $100 \mathrm{ml}$. was taken as an index of activity of the disease process, it was found that the FTA-ABS test was reactive in all save one of the twelve specimens with a raised cell count. This was

TABLE III Correlation of FT $A-A B S$ test on cerebrospinal fluid with cell count and protein level in 49 patients with neurosyphilis

\begin{tabular}{|c|c|c|c|c|c|c|}
\hline \multirow[b]{2}{*}{$F T A-A B S$ test } & \multicolumn{3}{|c|}{$W B C / c u . m m}$. & \multicolumn{3}{|c|}{ Protein ( $\mathrm{mg} . / 100 \mathrm{ml})}$. \\
\hline & $\leq 5$ & $>5$ & Not done & $\leq 40$ & $>40$ & Not done \\
\hline $\begin{array}{l}\text { Reactive } \\
\text { Negative }\end{array}$ & $\begin{array}{l}21 \\
14\end{array}$ & $\begin{array}{r}11 \\
1\end{array}$ & $\begin{array}{l}1 \\
1\end{array}$ & $\begin{array}{l}16 \\
12\end{array}$ & $\begin{array}{r}13 \\
2\end{array}$ & $\begin{array}{l}4 \\
2\end{array}$ \\
\hline
\end{tabular}

from a patient with adequately treated taboparesis; the cell count was 7 per cu. mm., the protein content within normal limits, and the other serological tests were negative. The FTA-ABS test was reactive in thirteen of the fifteen specimens with a raised protein level. The two exceptions had levels of 50 and $60 \mathrm{mg}$. per $100 \mathrm{ml}$. and came from patients with adequately treated tabes and asymptomatic neurosyphilis respectively; in both the cell count was normal and other serological tests on the CSF negative. Duncan and others (1972) found the FTA-ABS test reactive in nineteen of 38 patients with neurosyphilis and Mahoney, Haris, McCann, Kennedy, and Dougan (1972) found it positive in fifteen of twenty specimens from patients with clinical evidence of neurosyphilis, a similar incidence to that found in the present series.

Comparative reactivity of the unabsorbed FTA and FT A-ABS tests

The results of these tests on the specimens forming Groups $b$ and $c$ are combined in Table IV. Seventeen specimens were reactive in the unabsorbed FTA test but gave negative results with the FTA-ABS procedure. Five of the specimens giving discrepant results came from the hospital series (Group $b$ ); three were reactive only with undiluted CSF and two at a dilution of 1 in 5 . One of these last came from a patient who had had a cerebrovascular accident and the fluid was contaminated with blood which may have produced a false positive result. RPCF and VDRL tests were negative on all these five fluids and there was nothing to suggest syphilis in the clinical details supplied with the specimens. Twelve specimens giving discrepant results had been sent for confirmatory tests (Group $c$ ) and seven of these were reactive only with undiluted CSF. Two of these came from patients who had a history of treated syphilis, one of latent and the other of secondary syphilis. A further two patients had

TABLE IV Comparison of results of unabsorbed FTA and FTA-ABS tests on 158 cerebrospinal fluids

\begin{tabular}{|c|c|c|c|}
\hline \multirow[b]{2}{*}{ Unabsorbed $F T A$} & \multirow{2}{*}{$\begin{array}{l}\text { No. of } \\
\text { specimens }\end{array}$} & \multicolumn{2}{|c|}{$F T A-A B S$} \\
\hline & & Reactive & Negative \\
\hline Negative Neat & 120 & - & 120 \\
\hline $\begin{array}{l}\text { Reactive Neat } \\
\qquad \begin{array}{l}1 \text { in } 5 \\
1 \text { in } 15 \\
1 \text { in } 45 \\
1 \text { in } 135 \\
1 \text { in } 405 \\
1 \text { in } 1215\end{array}\end{array}$ & $\begin{array}{r}13 \\
5 \\
6 \\
3 \\
4 \\
5 \\
2\end{array}$ & $\begin{array}{l}3 \\
4 \\
3 \\
4 \\
5 \\
2\end{array}$ & $\begin{array}{l}10^{\mathrm{a}} \\
5^{\mathrm{b}} \\
2 \\
- \\
- \\
-\end{array}$ \\
\hline
\end{tabular}

aOther evidence of syphilis in four

bother evidence of syphilis in two 
reactive tests on their sera, including reactive TPI tests; one of these had spastic paraparesis and the other was a West Indian who had abnormal pupillary reactions. A further three fluids were reactive unabsorbed at a dilution of 1 in 5, although the FTA-ABS test was negative. In one, a patient with dementia, the TPI test was positive on both serum and CSF. The second patient was seropositive and complained of deafness; he was thought to have either congenital or latent syphilis. The third patient in this group was thought to have chronic meningitis; all other tests on the CSF, including the TPI test, were negative. The two fluids reactive unabsorbed at a dilution of 1 in 15 with negative FTA-ABS tests came from one patient with a history of 3 years' mental deterioration and from one with Paget's disease; other serological tests on the CSF were negative in both.

The unabsorbed FTA test on CSF is more sensitive than the FTA-ABS test in which CSF is diluted 1 in 5 in sorbent before testing. Among the seventeen specimens giving discrepant results, there were six from patients with other acceptable evidence of syphilis, four of whom showed neurological abnormalities. In the series reported by Harris and others (1960), two specimens from 59 patients presumed not to have syphilis were reactive undiluted and at a dilution of 1 in 10 respectively; one patient was found to have positive tests on his serum and syphilitic aortic insufficiency was found post mortem in the other. Vaisman and Hamelin (1961) found no false positive reactions in tests on 67 fluids classed as non-syphilitic, and Ripault and Colombani (1964) found none among 109 similar specimens. However, Escobar and others (1970) reported finding six reactive or weakly reactiveun absorbed FTA tests on CSF from 67 patients with no clinical or serological evidence of syphilis. Duncan and others (1972) found no positive unabsorbed FTA tests on 31 presumed non-syphilitic spinal fluids, although it was reactive in 20.9 per cent. of 361 spinal fluids from patients with syphilis at various stages compared with 9.4 per cent. reactivity in the FTA-ABS test. It is felt that, while the high sensitivity of the unabsorbed FTA test on CSF may make it useful as a screening procedure, further evaluation on more defined clinical material is needed before diagnostic significance can be attached to weakly reactive results in the absence of other changes in the CSF.

The interpretation of FTA results on CSF contaminated with blood is difficult. Izzat, Bartruff, Glicksman, Holder, and Knox (1971) showed experimentally that contamination of $1 \mathrm{ml}$. CSF with as little as $0.003 \mathrm{ml}$. blood with a VDRL titre of 1 in 256 could give a false positive VDRL result on the CSF. This amount of contamination is visible to the naked eye. Unabsorbed FTA titres on serum are usually considerably greater than 1 in 256 , so that the evaluation of FTA results on contaminated CSF must be made with caution, even when the blood is only visible microscopically.

\section{IgM anti-treponemal antibody in cerebrospinal fluid}

Tests were carried out on 38 specimens of CSF selected from Groups $b$ and $c$. CSF was tested undiluted and at a dilution of 1 in 5 in buffered saline and in Reiter ultrasonicate; a conjugate specific for IgM was used. The results are compared with the unabsorbed FTA titres and the FTA-ABS results in Table V. IgM antibody was detected in only four specimens, in three only with undiluted CSF and in one at a dilution of 1 in 5 ; all were negative when tested at a dilution of 1 in 5 in Reiter ultrasonicate. Two of these patients had neurosyphilis, but the test was negative on seventeen other fluids in the series from patients with neurosyphilis whose spinal fluids also showed positive serological tests. Of the two other patients with positive tests for IgM on their CSF, one had had a cerebrovascular accident, so that the result may well have been fallacious; the other had a history of mental deterioration. These results suggest that it is rare to find IgM anti-treponemal antibody in the CSF in neurosyphilis and agree with those of Mattern, Sandor, and Pillot (1965). These workers tested 35 specimens of CSF from patients with neurosyphilis; from their data on the cell count and protein levels, the disease was active in 24 patients. FTA tests on undiluted and unabsorbed CSF with

TABLE $\mathrm{V}$ Tests for IgM anti-treponemal antibody on 38 specimens of cerebrospinal fluid

\begin{tabular}{|c|c|c|c|c|}
\hline \multirow{3}{*}{$\begin{array}{l}\text { FTA titre } \\
(\text { unabsorbed })^{\mathrm{a}}\end{array}$} & \multicolumn{4}{|c|}{$F T A-A B S$ result ${ }^{\mathrm{a}}$} \\
\hline & \multicolumn{2}{|l|}{ Reactive } & \multicolumn{2}{|l|}{ Negative } \\
\hline & $\begin{array}{l}\text { IgM } \\
\text { negative }^{\mathrm{b}}\end{array}$ & $\begin{array}{l}\text { IgM } \\
\text { positive }^{\mathrm{b}}\end{array}$ & $\begin{array}{l}\text { IgM } \\
\text { negative }^{\mathrm{b}}\end{array}$ & $\begin{array}{l}\text { IgM } \\
\text { positive }^{\mathrm{b}}\end{array}$ \\
\hline Negative & 一 & 一 & 6 & - \\
\hline $\begin{array}{l}\text { Reactive Neat } \\
\begin{array}{l}1 \text { in } 5 \\
1 \text { in } 15 \\
1 \text { in } 45 \\
1 \text { in } 135 \\
1 \text { in } 405 \\
1 \text { in } 1215\end{array}\end{array}$ & $\begin{array}{l}2 \\
5 \\
3 \\
4 \\
5 \\
-\end{array}$ & $\begin{array}{l}- \\
\bar{z} \\
2^{e}\end{array}$ & $\begin{array}{l}6 \\
- \\
- \\
- \\
-\end{array}$ & $\begin{array}{l}\overline{1 c} \\
1^{\mathrm{d}} \\
- \\
\overline{-} \\
-\end{array}$ \\
\hline
\end{tabular}

aAnti-human immunoglobulin conjugate

bspecific anti-human IgM conjugate

cerebrovascular accident. CSF bloodstained

d3 yrs mental degeneration

eNeurosyphilis 
conjugates specific for IgM and IgA were negative on all 35 specimens, although IgM globulin was demonstrable in the CSF by gel diffusion in sixteen. Oxelius, Rorsman, and Laurell (1969) have shown that the levels of $\operatorname{IgG}$ and $\operatorname{IgM}$ in the cerebrospinal fluid are increased in neurosyphilis. After treatment, the IgG level falls slowly, but the IgM level much more rapidly.

\section{Summary}

(1) FTA-ABS tests were done on cerebrospinal fluid (CSF) from 289 patients with syphilis at various stages of the disease. In the 49 with neurosyphilis it was reactive in 67 per cent. and was more sensitive than the Reiter protein complementfixation test, the VDRL test, or the cardiolipin Wassermann reaction. It was reactive in almost all specimens in which a raised cell count or protein level suggested activity of the disease.

(2) The FTA test on undiluted and unabsorbed CSF was compared with the FTA-ABS test on 158 specimens. The unabsorbed FTA test, although more sensitive than the FTA-ABS procedure, gave some unexplained results. It can be used as a screening test, but further evaluation is needed before its diagnostic significance can be assessed. (3) Tests for IgM anti-treponemal antibody were found positive in only two of nineteen cerebrospinal fluids from patients with neurosyphilis.

My thanks are due to Miss R. Barteluk for her technical assistance, to colleagues at the Whitechapel Clinic and Moorfields Eye Hospital for help with clinical assessments, and to the World Health Organization for a financial grant. Dr. P. O'Neill kindly supplied one specimen of IgM-reactive CSF.

\section{References}

Duncan, W. P., Jenkins, T. W., and Parham, C. E. (1972) Brit. F. vener. Dis., 48, 97

Escobar, M. R., Dalton, H. P., and Allison, M. J (1970) Amer. F. clin. Path., 53, 886
Garner, M. F., and Backhouse, J. L. (1971) Brit. $\mathcal{F}$. vener. Dis., 47, 356

Harris, A., Bossak, H. M., Deacon, W. E., and Bunch, W. L. (1960) Ibid., 36, 178

IZZAT, N. N., BARTRUFF, J. K., GlickSMAN, J. M., HOLDER, W. R., and KNox, J. M. (1971) Ibid., 47, 162

Mahoney, J. D. H., HaRRIS, J. R. W., McCanN, J. S., KenNedy, J., and Dougan, H. J. (1972) Acta derm.venereol. (Stockh.), 52, 71

Mattern, P., Sandor, G., and Pillot, J. (1965) Ann. Inst. Pasteur, 109, Suppl. to No. 5, p. 120

O’NeIll, P., and NiCol, C. S. (1972) Brit. F. vener. Dis., 48, 460

Oxelius, V.-A., Rorsman, H., and Laurell, A-B. (1969) Ibid., 45, 121

Public Health Laboratory Service (1972) Monograph Series No. 1, 'Laboratory Diagnosis of Venereal Disease'. H.M. Stationery Office, London

Ripault, J., and Colombani, J. (1964) Path. et Biol., 12, 276

Vaisman, A., and Hamelin, A. (1961) Presse méd., 69, 1157

Tests à l'anticorps fluorescent tréponémique sur le liquide céphalo-rachidien

SOMMAIRE

(1) Des tests FTA-ABS furent effectués sur le liquide céphalo-rachidien (LCR) de 289 malades atteints de syphilis à des stades divers de la maladie. Chez 49 des malades atteints de syphilis nerveuse, le test fut positif dans 67 pour cent des cas et plus sensible que l'épreuve de fixation du complément à l'antigène de Reiter, que le VDRL et que la réaction de Wassermann à la cardiolipine. L'épreuve fut positive sur presque tous les échantillons dans lesquels une augmentation de la réaction cellulaire ou du taux des protéines faisaient penser à l'état d'activité de la maladie.

(2) Sur le LCR, le test FTA non dilué et non absorbé a été comparé avec le FTA-ABS sur 158 échantillons. L'épreuve FTA non absorbée, quoique plus sensible que le FTA-ABS, a donné quelques résultats inexpliqués. Elle peut être utilisé comme épreuve de détection, mais une évaluation ultérieure est nécessaire avant que l'on puisse affirmer sa signification diagnostique.

(3) Les épreuves pour l'anticorps antitréponémique IgM furent trouvées positives dans deux LCR seulement chez 19 malades atteints de neuro-syphilis. 